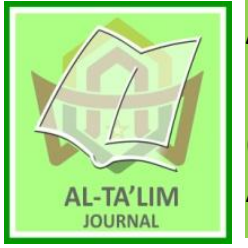

AL-TA'LIM JOURNAL, 25 (2), 2018, (163-170)

(Print ISSN 1410-7546 Online ISSN 2355-7893)

Available online at http://journal.tarbiyahiainib.ac.id/index.php/attalim

\title{
The Effect of Communication Games and Self-Esteem towards Students' Speaking Skill
}

Received: $13^{\text {th }}$ February 2018; Revised:01 ${ }^{\text {th }}$ March 2018; Accepted: $24^{\text {th }}$ July 2018

Permalink/DOI: http://dx.doi.org/10.15548/ it.v25i2.398

\section{Rifky Fakhrurrazy *)}

Universitas Negeri Padang, Padang, Indonesia.

E-Mail: rifkyazka.rf@gmail.com

\section{Hermawati Syarief}

Universitas Negeri Padang, Padang, Indonesia.

E-Mail: hermasyarief@gmail.com

*) Corresponding Author

\begin{abstract}
Abstract: This research is an experimental research. This study aims to find out the effect of communication games as a teaching strategy and self-esteem toward students speaking skill at SMP Dr. Abd Ahmad PGAI Padang. The population of this research was students of grade VIII SMP Dr. Abd Ahmad PGAI Padang. The technique used is Cluster Random Sampling. The sample consists of students at VIII A as experimental class and VIII B as control class. In this research, the test is used to analize students' speaking skill and questionnaire was used to collect self-esteem data. Data from the research were analyzed by using two-way t-test and ANOVA (ANOVA $2 \times 2)^{4}$. The results of this research were (1) students taught with Communication Game have better speaking skills than students taught by conventional strategies, (2) the speaking skill of students with high self-esteem with Communication Game gives higher results than Conventional teaching strategies, (3) students 'speaking skills with low Self-Esteem with Communication Game gives higher results than conventional teaching strategies, and (4) there is no interaction between strategy and Self-Esteem in transactional text.
\end{abstract}

Keywords: Teaching; speaking; communication games; self-esteem.

How to Cite: Fakhrurrazy, R. \& Syarief, H. (2018). The effect of communication games and self-esteem towards students' speaking skill. Al-Ta Lim Journal, 25(2). http://dx.doi.org/10.15548/ jt.v25i2.398

\section{INTRODUCTION}

Communication skills in a foreign language clearly and efficiently contribute to the success of language learner in school and success later in every phase of life. Therefore, it is essential for language teacher to pay great attention to teach speaking. Teaching speaking is a very important part of language learning. By learning speaking, the students will know the way to express their ideas, opinion, feelings, and emotion meaningfully. Besides that, it also leads them to make interaction in the society by using the language.

The national curriculum regulation, Curriculum (Curriculum 2013) requires the students to be able to communicate in English. In this curriculum, the aim of teaching English to Junior High School is to understand knowledge (factual, conceptual, and procedural) based on students' curiosity about science, technology, arts, culture and events related phenomena. They should try, process, and present in the realm of concrete (using, parse, compose, modify, and create) and the realm of the abstract (writing, reading, counting, drawing, and fabricated) according to the learned in schools and other sources in the same view point or theory. Then, the students have to complete the core competence that is described in basic competence and the indicators in syllabus, in order to reach the value of completeness. It 
means that speaking is one of the competences that should be taught by teacher and be mastered by students.

In this situation, teachers should help their students in learning vocabularies so that they can use English in their classroom activities. Consequently, the teachers should be more creative: in finding materials, media, methods, or techniques; they also give good models during their learning process. For example, the teacher can use various learning techniques in order to improve their students' ability.

Based on the observation in SMP Dr. Abdullah Ahmad PGAI Padang, many students still could not speak English well. It can be seen from students' speaking achievement. The mean score of students' speaking test especially at grade VIII was only 53.40, the mean score of students did not reach the standard of the school that is 70 . From 133 students, only $35.6 \%$ passed the standard. It means that there was a gap between Minimum Criteria and the real condition in the field namely students; score of speaking skill.

After interviewing the English teacher and some students in SMP Dr. Abd Ahmad PGAI Padang, the researcher found the problem. One of the problems was the lack of spoken English practice. For example, when they were asked to tell something they often used the same words for a few times. Then, the conversation activities showed that they still could not get the message from their friends speaking or vice versa and they didn't know how to pronounce the words. During the speaking activity students often focused on the meaning rather than understanding of the message. It means that the students could not optimally involve in speaking activities because they did not have any ideas when the teacher asked them to speak. They had something in their mind but they actually thought much more about the vocabularies and appropriate words when they expressed their ideas. Indeed, it results on the students' reluctance in speaking. Although speaking is now an essential part of many language curricula, in fact speaking is less frequently taught and occurred in the classroom. Moreover, once the speaking skill is taught, the English teacher only uses the conventional strategy such as memorization of dialogue from the text books and the students perform it in front of the class with pairs. Sometimes the teacher also encourages the students to speak up by asking the questions, but it is not effective enough. Here not all the students get the equal chances to practice their speaking. Only some dominant students participate actively in classroom talk. This condition makes reserved students difficult to express theme self freely. Dominants students who interrupt frequently or who constantly look for the teacher's attention tend to create a condition where the other is quite happy to sit back and watch the lesson instead of participating.

Speaking is one of the skills in English. It plays an important role in studying the subject, because English is generally known an international language. As international language, English is used in many communication media, such as public information, newspaper, television, internet and academic books. Speaking is an interaction between two or more people orally. They use language for interaction and transactional purpose. It means at least there are two speakers. One person will be a speaker, and the other will be listener. They usually exchange their position (as a speaker or as a listener). Speaking is to express thoughts a loud using the voice or talk. O'malley \& Pierce, (1996), define that speaking mean negotiating intended meaning and adjusting one's speech to produce the desired effect on the listeners also categorizes types of speaking into "verbal essay, oral presentation, of free interview, the controlled interview, information transfer (description of a picture sequences, questions on a single picture), interaction and role play.

Based on some literatures, there is an interesting strategy in teaching speaking. This strategy is called Communication Games. There are some literatures that propose this 
strategy to be taught in teaching English. Nurkasih (2010) she find communicative games can improve students' speaking skill. She concluded that communicative games can improve students' speaking skills at grade VIII.1 SMPN Batusangkar well. Therefore she implemented communicative games to improve students' speaking skill in speaking class. Astati (2009) found that the students' speaking skill by using Board Game could better improve than their speaking skill before the research was conducted. This strategy provides more interaction among the learners; it gives the learners a lot of opportunities to learn among them. This strategy also provides fun activities; they do some actions (standing, walking and yelling). Therefore, this strategy is suitable to young learners which love playing games, learning by doing and interacting to others during their learning.

Von Ahn (2006) state that a game is an activity with rules a goal and element of fun. There are some exciting games in his book such as great shopping race game, lost in the post happy birthday game, restaurant game, blind date game, don't worry game, restaurant game and Class Color game attempted in this research. The games are chosen in teaching speaking since students' expression of indicate that they enjoy playing games. In particular, once they feel enjoy doing one work, it is even easier to guide and have them involved in participating at any certain classroom activities The researcher believes that Communication Game can be considered in teaching speaking because it is a democratic activity that encourages understanding between the students. Based on previous findings, there are some advantages of using Communication Game in students' speaking skill and their self-esteem. It will increase students' skill in speaking without being afraid of getting mistakes. Those are the reasons to choose this Communication Games to overcome the problems.

The other research that deal with selfesteem was found in the research conducted by Tremblay, Inman, \& Willms (2000) he has done a research about The Relationship
Between Self-Esteem and Speaking Skill. He has done research in four public senior high schools at North Minahasa, the sample of this research were the student in grade eleventh. $\mathrm{He}$ found that there were moderate level of students' self-esteem and moderate level of speaking skill. Moreover, the moderate level also found between self-esteem and speaking skill. In other word, level of students' selfesteem has a relation or can give influence to their speaking skill.

\section{METHOD}

This study is an experimental research. This research was aimed at investigating the effect of a teaching strategy toward speaking skill (Gersten et al., 2005; Wiersma \& Jurs, 2005). In this research, the experimental group (Communication games) was compared with the control group (Conventional teaching strategy) in mastering speaking skill. In addition, the self-esteem was also involved in this research. It was divided into high selfesteem and low self-esteem. In short, this research was intended to find out the effect of Communication games as independent variable toward speaking skill as dependent variable, while self-esteem as the moderator variable. Factorial design was used in this research because it had more than one independent variable. Best \& Kahn (2016); Carr \& Kemmis (2003) state that "When more than one independent variable is included in a study, whether a true experiment or a quasiexperiment, a factorial design is necessary." Since there were two independent variables (strategy and self-esteem) with two conditions of each, 2 x 2 factorial design was used. In addition, Posttest-only design was also used in this research; there was no pretest. It was intended to avoid internal validity threats of testing and instrumentation (Creswell, 2002). When the samples were selected, the treatment for the experimental group and the control group was given; and a post-test was assigned. The population of this research was the grade eight at SMP Dr. Abd Ahmad PGAI Padang, in academic year 2014/2015. This population was chosen because it was suitable with the researcher's interest. They have 
certain characteristics and quality as the researcher expected. The instruments of this research were an oral performance test and questionnaires. Those instruments were used since they were suitable for this research. The instruments (test and questionnaires) were consulted to validate before they were used in order to know whether the instruments were valid or not. The tests were used for posttest only. The collected quantitative data was students' scores. The data implied the level students' speaking skill. Meanwhile, the questionnaires were given at the first meeting. It was used to collect self-esteem data. It consisted of 10 items that were analyzed to describe their self-esteem in learning.

\section{RESULT AND DISCUSSION}

The hypothesis testing 1 can be seen in the following table:

Table 1. Hypothesis Testing 1

\begin{tabular}{cccc}
\hline Technique & $\mathbf{t}_{\text {observed }}$ & $\mathbf{t}_{\text {table }}$ & Note \\
\hline Communic & 4.272 & 1.671 & $t_{\text {observed }}$ \\
ation Game & & & $>t_{\text {table }}$ \\
& & & Ha: \\
& & & accepted \\
\hline
\end{tabular}

The value of $t_{\text {observed }}$ is 4.272 and $t_{\text {table }}$ is 1.671. It means that $t_{\text {observed }}$ is higher than $t_{\text {table. }}$. It can be concluded that $\mathrm{H}_{1}$ is accepted and $\mathrm{H}_{0}$ is rejected; Communication games get significant higher result in speaking skill at SMP Dr. Ahmad PGAI Padang than who are taught by conventional teaching strategy.

Then, from second hypothesis, it can be stated that:

Table 2. Hypothesis Testing 2

\begin{tabular}{lccl}
\hline Technique & $\mathrm{t}_{\text {observed }}$ & $\mathrm{t}_{\text {table }}$ & Note \\
\hline Communic & 3.513 & 1.753 & $t_{\text {observed }}$ \\
ation & & $>t_{\text {table }}$ \\
Game & & Ha: \\
& & accepted \\
\hline
\end{tabular}

The value of $\mathrm{t}_{\text {observed }}$ is 3.513 and $\mathrm{t}_{\text {table }}$ is 1.753. It means that $t_{\text {observed }}$ higher than $t_{\text {table }}$. It can be concluded that $\mathrm{H}_{1}$ is accepted and $\mathrm{H}_{0}$ is rejected; High self-esteem who are taught by communication game gives significant higher result on students speaking skill of transactional text than those who are thought conventional teaching strategy.

Table 3. Hypothesis Testing 3

\begin{tabular}{llccccc}
\hline Sum of Variance & Sum of Square & df & Mean Square & F Value & Sig & F Table \\
\hline $\begin{array}{l}\text { Interrow } \\
\text { (Technique) }\end{array}$ & 1568.000 & 1 & 1568.000 & 21.406 & 0.000 & 2.547 \\
$\begin{array}{l}\text { Inter column } \\
\text { (Self-esteem) }\end{array}$ & 112.500 & 1 & 112.500 & 1.536 & 0.266 & 2.457 \\
$\begin{array}{l}\text { Interaction } \\
\text { Error }\end{array}$ & 188.071 & 1 & 188.071 & 1.622 & 0.211 & 2.457 \\
Total & 3942.444 & 34 & 115.954 & & & \\
& $\mathbf{1 7 9 8 7 2 . 0 0 0}$ & $\mathbf{3 8}$ & & & & \\
\hline
\end{tabular}

It means that $t_{\text {observed }}>t_{\text {table. }}$. It can be concluded that $\mathrm{H}_{0}$ is rejected and $\mathrm{H}_{1}$ is accepted. Low self-esteem who are taught through Communication games gives higher result on students speaking skill of transactional text than those who are taught through conventional teaching strategy.
In addition, in hypothesis fourth testing, it is found that: the score of $F_{\text {calculated }}$ is 1.622 and the score of $F_{\text {table }}$ is 2.457. It can be concluded that $\mathrm{F}_{\text {calculated }}<\mathrm{F}_{\text {table, }}$, it means $\mathrm{H}_{0}$ is accepted. It can be said that there is no interaction between those techniques (Communication games and conventional 
teaching strategy) and self-esteem students' speaking skill.

Communication Games significantly has better result on students speaking skill of transactional text at SMP Dr Abd Ahmad PGAI Padang than those conventional teaching strategy.

Based on the statistical analysis of hypothesis testing, it was found that the students' mean scores in experimental class are higher than those in control class. In other words, the Communication game has better result on students' speaking skill of Transactional text.

Communication Game gave more opportunity for the students to practice their speaking skill. Students were trained to communicate their idea in groups. Students had superiority in developing and communicating their idea of the material given orally and they can also develop their own social skill through interaction with their partner (Tanaka, Kuwahara, Oe, \& Yoshioka, 2011; Yamashita \& Satou, 2005).

The implementation of communication language games better improve the students speaking skill. It was proven by the students speaking score in experimental class which was higher than that the students speaking score in control class. It is in line with the previous research finding conducted by Nurkasih (2010) about improving students' speaking skill through Communicative Games at VIII.1 Grade of SMPN 4 Batusangkar. She found that communicative games improve students' speaking skill at SMPN 4 Batusangkar well. It means that communication games can be used as an alternative for teacher to teach speaking skill because it's able to help students to improve their speaking skill. Then this finding is also in line with Kim, Park, \& Baek (2009); Liu \& Chu (2010) the teacher can get many advantages besides getting easy to learn speaking, the students can develop their opinion, their way to thinking, their interests of some material. Communication Game makes students' enjoy and have fun in studying English, make students share, give ideas, opinion and expressing feeling each other.

In both Communication game and Conventional Teaching Strategy, the students got more maximum time to speak target language by providing tasks, material and shared knowledge. In this research, the teacher reduced her talking time in class to add chances the students to speak. It means that the researcher develops oriented learners in speaking English. The different result for both experimental classes depends on students' ability to maximize the chances and result findings show that Communication game gets higher result because the students have more chances to speak.

Communication game gives higher result to students speaking skill who have high self-esteem at grade eight of SMP Dr. Abd Ahmad PGAI Padang than Conventional teaching strategy.

Based on the result of the second hypothesis, it is found that the mean score of students' speaking skill of transactional text with high self-esteem taught by using Communication Game has higher result than taught by Conventional Teaching.

In addition (Maleki \& Mohammadi, 2009) found that the more successful students had the higher self-esteem than they who had less successful in speaking or oral communication. Self-esteem gave significant contribution to someone while speaking. In fact it is needed for students to have high selfesteem in order to help them at least in conveying their opinion about something, or they need enough self-esteem in answering a question delivered by someone to them.

High self-esteem is partly the result of good school performance. High self-esteem makes people more willing to speak up in groups and to criticize the group's approach. It means that the students with high self-esteem lead students to their good performance in the class room. Besides performing persistently, 
they also have high belief to recognize what they can do. The different mean score of students' speaking skill achieved by both classes is influenced by some factors. First, the experimental class taught by communication game got more opportunities to develop themselves in participating in the classroom than the class taught by Conventional Teaching. Second, in both communication Game and Conventional Teaching, the students got more maximum time to speak target language by providing tasks, material and shared knowledge. In this research, the teacher reduced her talking time in class to add chances the students to speak. It means that the researcher develops oriented learners in speaking English. The different result for both experimental classes depends on students' ability to maximize the chances and result findings show that Communication game gets higher result because the students have more chances to speak.

\section{Communication game gives higher result to students speaking skill who have low self-esteem at grade eight of SMP Dr. Abd Ahmad PGAI Padang than Conventional teaching strategy.}

Based on the result of the third hypothesis, the score of students' speaking skill of Transactional Text with low selfesteem taught by Communication Game has better result than that taught by Conventional Teaching Strategy, it means that the students who had low self-esteem tend to doubt to their ability in accomplishing or performing task.

The result of testing in the third hypothesis shows that students' speaking skill with low self-esteem taught by using Communication Game is not significantly higher than those taught by Conventional teaching strategy compared with students' speaking skill with low self-esteem. There is something new of finding that the researcher found in this research. The means score of students' speaking skill with low self-esteem taught by communication Game is not significantly higher than those taught by
Conventional teaching Strategy. Despite their self-esteem is low, but there is another factor influence the result, that is intelligence. But of course the result of the students' speaking skill with low self-esteem is not better than those with high-self-esteem.

To sum up, the students with low selfesteem tend to have lower performance in their speaking because they do not have high belief to perform well. They have low judgment toward their skill in speaking English.

There is no interaction between those techniques (Communication Games and Conventional teaching strategy) and selfesteem toward students' speaking skill.

Based on result of the fourth hypothesis, based on the result of testing the fourth hypothesis, there is no interaction between Communication game and Conventional Teaching with self-esteem toward students' speaking skill of transactional texts. It is found that alternative hypothesis $\left(\mathrm{H}_{1}\right)$ is rejected and null hypothesis $\left(\mathrm{H}_{0}\right)$ is accepted. If the null hypothesis is accepted, there is an implication that there is no interaction between Communication Game and conventional Teaching with students' self-esteem toward students' speaking skill of transactional texts. This is in line with the theory proposed by Creswell (2002); Gay, Mills, \& Airasian (2009) who state that the line of those variables do not cut one another but ordinal lines, it means that there is no interaction between the variables.

The chart shows that there are two parallel ordinal lines. It means that there is no interaction between the used of Communication game and Conventional toward students' speaking skill of transactional texts. But the data show that Communication game is better than Conventional Teaching strategy toward students' speaking skill from the mean scores of students' speaking skill. 
In other words, Communication game and Conventional Teaching give positive results toward students' speaking skill and students' self-esteem. If it is seen from the mean score of students' speaking skill, there is possibility that there is interaction between students' self-esteem and students' speaking skill. This is related to the second and third hypothesis. The students with high selfesteem get the higher scores than those with low self-esteem toward speaking skill.

In conclusion, there is no interaction between teaching strategy (Communication Game and Conventional Teaching) and selfesteem toward students' speaking skill. In fact the data show that communication games were better than conventional teaching strategy toward students" speaking skill from the mean scores of students "e speaking ability. Self-esteem encourages students to speak English. But, based on the statistical calculation, the interaction between techniques used and self-esteem cannot affect students' speaking skill of Transactional Texts.

\section{CONCLUSION AND RECOMMENDATION}

Based on the research findings can be drawn several conclusion. First, the communication game was very beneficial as investment of teaching speaking skill. It gives significant effect on students' speaking skill. It can be seen from the scores of students' speaking skill in experimental class taught by using communication games are significantly higher than the score of students' speaking skill in control class taught by conventional teaching.

Second, students`speaking skill with high self-esteem were taught by Communication Game get significantly higher score than students' speaking skill that have high self-esteem that taught by conventional teaching. It mean that the communication game is effective strategy to increase students' speaking skill with high self-esteem.
Third students` speaking skill with low self-esteem were taught by Communication Game get significantly higher score than students' speaking skill that have low self-esteem that taught by conventional teaching.

And last, both of teaching strategy (communication game and conventional teaching strategy) and self-esteem do not have interaction that brings impact on students speaking skill directly.

Based on the findings and conclusions above, the researcher would like to propose suggestions as follow: (1). From the research findings of this research, Communication Game was the effective way to improve students' speaking skill in transactional text at the second grade of SMP Dr Abd Ahmad PGAI Padang. Therefore, it is suggested that English teachers at SMP Dr Abd Ahmad PGAI Padang apply Communication Game as a variation of teaching speaking techniques. (2). It is suggested that the English teacher apply this technique because it gives benefit for the students, the students can practice their English more with their friend. (3). It is suggested for further researcher to develop this research on larger population and sample in order to get the knowledge and the empiric data. Besides that, they also suggested to conduct the same research for other skill and other kind of text.

\section{REFERENCES}

Best, J. W., \& Kahn, J. V. (2016). Research in education. Pearson Education India.

Carr, W., \& Kemmis, S. (2003). Becoming critical: education knowledge and action research. Routledge.

Creswell, J. W. (2002). Educational research: Planning, conducting, and evaluating quantitative. Prentice Hall Upper Saddle River, NJ.

Gay, L. R., Mills, G. E., \& Airasian, P. W. (2009). Educational research: Competencies for analysis and 
applications, student value edition. Upper Saddle River, NJ: Merrill.

Gersten, R., Fuchs, L. S., Compton, D., Coyne, M., Greenwood, C., \& Innocenti, M. S. (2005). Quality indicators for group experimental and quasi-experimental research in special education. Exceptional Children, 71(2), 149-164.

Kim, B., Park, H., \& Baek, Y. (2009). Not just fun, but serious strategies: Using meta-cognitive strategies in gamebased learning. Computers \& Education, 52(4), 800-810.

Liu, T.-Y., \& Chu, Y.-L. (2010). Using ubiquitous games in an English listening and speaking course: Impact on learning outcomes and motivation. Computers \& Education, 55(2), 630643.

Maleki, N., \& Mohammadi, A. (2009). Selfesteem and Anxiety of Iranian EFL Learners in Oral Communication Tasks. Journal of Linguistic Studies, 2(2), 47-54.

Nurkasih, S. (2010). Improving students' speaking skill through communicative group technique ( $\mathrm{PhD}$ Thesis). Universitas Sebelas Maret.

O'malley, J. M., \& Pierce, L. V. (1996). Authentic assessment for English language learners: Practical approaches for teachers. AddisonWesley Publishing Company New York.

Tanaka, S., Kuwahara, M., Oe, T., \& Yoshioka, T. (2011). Wireless communication game system.

Tremblay, M. S., Inman, J. W., \& Willms, J. D. (2000). The relationship between physical activity, self-esteem, and academic achievement in 12-year-old children. Pediatric Exercise Science, 12(3), 312-323.

Von Ahn, L. (2006). Games with a purpose. Computer, 39(6), 92-94.

Wiersma, W., \& Jurs, S. G. (2005). Research methods in education: An introduction.

Yamashita, N., \& Satou, M. (2005). Communication game system and communication game processing method. 